\title{
PENGEMBANGAN PERANGKAT PEMBELAJARAN PENDIDIKAN MATEMATIKA REALISTIK (PMR) BERBASIS ETHNOMATHEMATICS SEBAGAI UPAYA MENGEMBANGKAN KREATIVITAS SISWA
}

\author{
Indah Budiarti, Winda Agustina \\ STKIP PGRI Banjarmasin \\ ndhbdrt@gmail.com,winda.agustina@stkipbjm.ac.id
}

\begin{abstract}
Abstrak: Prinsip pembelajaran hendaknya diterapkan dengan adanya pengakuan atas perbedaan individual dan latar belakang budaya siswa. Ethnomathematics merupakan jembatan antara budaya dengan matematika. Melalui PMR (Pendidikan Matematika Realistik) yang berbasis ethnomathematics, siswa diharapkan dapat lebih mengembangkan kreativitasnya dengan memahami implementasi matematika sesuai dengan latar belakang budayanya, sehingga nilai budaya yang merupakan bagian dari karakter bangsa dapat tertanam sejak dini. Tujuan penelitian ini adalah mengembangan perangkat pembelajaran matematika yang baik mengunakan model pengembangan Plomp yang terdiri dari beberapa tahap yaitu (1) Tahap investigasi awal, (2) Tahap perancangan, (3) Tahap realisasi, dan (4) Tahap tes, evaluasi, dan revisi. Kriteria kualitas suatu produk oleh Nieveen digunakan untuk mendapatkan perangkat pembelajaran baik yaitu (1) valid, (2) praktis, dan (3) efektif. Perangkat pembelajaran yang dikembangkan berupa Rencana Pelaksanaan Pembelajaran (RPP), Lembar Kerja Siswa (LKS) dan Tes Kreativitas Siswa (TKS). Hasil Penelitian berupa perangkat pembelajaran pendidikan Matematika Realistik (PMR) berbasis Ethnomathematics sebagai upaya mengembangkan kreativitas siswa yang baik yaitu valid, praktis dan efektif.
\end{abstract}

Kata Kunci: Pengembangan, Realistik, Ethnomathematics, Kreativitas

Beberapa prinsip pembelajaran yang hendak diterapkan di kelas adalah (1) dari siswa diberi tahu menuju peserta didik mencari tahu, (2) dari pembelajaran verbalisme menuju keterampilan aplikatif, (3) pembelajaran yang menerapkan nilai-nilai dengan memberi keteladanan (ing ngarso sung tulodo), membangun kemauan (ing madyo mangun karso), dan mengembangkan kreativitas peserta didik dalam proses pembelajaran (tut wuri handayani); dan (4) adanya pengakuan atas perbedaan individual dan latar belakang budaya siswa (Kemdikbud, 2013)

Pembelajaran dilaksanakan berbasis aktivitas dengan karakteristik: (1) interaktif dan inspiratif; (2) menyenangkan, menantang, dan memotivasi peserta didik untuk berpartisipasi aktif; (3) kontekstual dan kolaboratif; (4) memberikan ruang yang cukup bagi prakarsa, kreativitas, dan kemandirian peserta didik; dan (5) sesuai dengan bakat, minat, kemampuan, dan perkembangan fisik serta psikologis peserta didik (Kemdikbud, 2014).

Prinsip pembelajaran hendaknya diterapkan adalah adanya pengakuan atas perbedaan individual dan latar belakang budaya siswa. Ethnomathematics merupakan jembatan antara budaya dengan matematika. Melalui PMR (Pendidikan Matematika Realistik) yang berbasis ethnomathematics, siswa diharapkan dapat lebih mengembangkan kreativitasnya dengan memahami implementasi matematika sesuai dengan latar belakang budayanya, sehingga nilai budaya 
yang merupakan bagian dari karakter bangsa dapat tertanam sejak dini.

\section{Pendidikan Matematika Realistik} (PMR) merupakan salah satu pendekatan dalam pembelajaran matematika yang dikembangkan oleh Hans Freudenthal yang berpendapat matematika merupakan suatu aktivitas manusia. Melalui aktivitas ini dengan prinsip "guided reinvention" menuntun siswa untuk menemukan kembali ide dan konsep matematika dengan bimbingan orang dewasa. Freudenthal (dalam Gravemeijer, 1999: 116) menekankan prinsip guided reinvention pada karakter proses pembelajaran, bukan pada apa yang ditemukan. Menurut Slettenhar (dalam Ningsih, 2014), aktivitas dilakukan melalui penjelajahan berbagai situasi dan persoalan "realistik". Realistik yang dimaksudkan tidak sekedar menunjukkan hubungan dengan dunia nyata, tetapi lebih berfokus pada sesuatu yang dapat dibayangkan siswa untuk melakukan matematisasi (pematematikaan).

Pembelajaran dengan pendekatan PMR memiliki beberapa karakteristik yang dikemukakan oleh Hobri (2009). Adapun karakteristik PMR antara lain sebagai berikut: 1. Menggunakan masalah kontekstual (the use of contex)

Pembelajaran dimulai dengan menggunakan masalah kontekstual. Konteks tidak harus berupa masalah dunia nyata, namun bisa dalam bentuk penggunaan alat peraga, bahan manipulatif atau hal yang bisa dibayangkan dalam pikiran siswa. Melalui penggunaan konteks, siswa terlibat aktif dalam kegiatan mengekplorasi permasalahan.

2. Menggunakan model (use models)

Pada pembelajaran dengan pendekatan PMR, model dijadikan sebagai jembatan antara masalah real dengan matematika abstrak dan digunakan dalam melakukan matematisasi secara progresif. Siswa membuat model matematikanya sendiri untuk menyelesaikan masalah.

3. Menggunakan kontribusi siswa (student contribution)

Matematika tidak diberikan sebagai suatu produk yang siap dipakai. Pada pembelajaran dengan pendekatan PMR, matematika diberikan sebagai suatu konsep yang dibangun oleh siswa dimana siswa ditempatkan sebagai subjek belajar. Siswa diberi kebebasan untuk mengembangkan strategi pemecahan masalah sehingga diharapkan akan diperoleh strategi penyelesaian masalah yang bervariasi.

4. Interaktivitas (interactivity)

Pada proses pembelajaran, seseorang belajar bukan hanya sebagai suatu proses individu melainkan juga suatu proses sosial. Melalui komunikasi, hasil kerja dan gagasan ide-ide antar siswa diharapkan menjadikan proses pembelajaran menjadi lebih singkat dan bermakna. Sebagai contoh, setting pembelajaran kooperatif dapat membantu menciptakan interaksi sosial di dalam kelas. Melalui pembelajaran kooperatif, siswa bekerja secara kolaboratif untuk mencapai tujuan bersama (Trianto, 2011).

5. Terintegrasi dengan topik lainnya (intertwining)

PMR menempatkan keterkaitan antar konsep matematika sebagai hal yang harus dipertimbangkan dalam proses pembelajaran. Melalui keterkaitan ini, suatu pembelajaran matematika diharapkan bisa mengenalkan atau membangun lebih dari satu konsep matematika secara bersamaan.

Etnomatematika berasal dari kata ethno (budaya yang dibentuk oleh masyarakat), mathema (penjelasan, pemahaman, lingkungan akan budaya), dan tics (mode, gaya, teknik). D'Ambrosio (1997) menjadi "Bapak Intelektual" dari program etnomatematika yang diusulkan sebagai 
konsep yang lebih luas dari etno atau budaya. Etnomatematika jika diterapkan di kelas akan menjadikan pembelajaran semakin bermakna dan akan lebih baik jika diterapkan di kelas multikultural (beragam suku, budaya, bahas, jenis kelamin, dan lainnya). Menurut Royani dan Agustina (2017), etnomatematika merupakan integrasi matematika dan budaya dengan kearifan lokal kelompok setempat melalui suatu aktivitas.

Banjarmasin memiliki keragaman budaya dengan ciri khas masyarakat Banjar yang sangat erat hubungannya dengan sungai, rawa, danau, atau pegunungan. Dalam kesehariannya, siswa hidup sebagai masyarakat dan menjadi bagian dari budaya Banjar tersebut. Pembelajaran matematika hendaknya memberikan manfaat kepada siswa dalam kehidupannya sesuai dengan cara hidupnya di masyarakat.

Dreavdahl (dalam Ngalimun dkk, 2013) mendefinisikan kreativitas sebagai kemampuan untuk memproduksi komposisi dan gagasan-gagasan baru yang dapat berwujud kreativitas imanjinatif atau sintesis yang mungkin melibatkan pembentukan polapola baru dan kombinasi dari pengalaman masa lalu yang dihubungkan dengan yang sudah ada pada situasi sekarang

Menurut Laurence (dalam Wijaya, 2012), kreativitas merupakan salah/satu keterampilan yang bisa dipelajari. Keterampilan tidak hanya bakat alami, tetapi juga merupakan suatu proses yang dapat ditingkatkan melalui kesadaran dan latihan (Adams \& Hamm, 2010). Setiap anak memang memiliki potensi kreatif sejak kecil, akan tetapi mereka membutuhkan suatu lingkungan pembelajaran yang mendukung potensi kreatif mereka agar berkembang dengan maksimal.

Sebuah perangkat pembelajaran yang dapat mengembangkan kreativitas siswa sesuai dengan latar budaya siswa sendiri sangat diperlukan. Oleh karena itu pengembangan perangkat pembelajaran ini dibuat.

\section{Metode Penelitian}

Penelitian ini digolongkan sebagai penelitian pengembangan untuk menghasilkan perangkat pembelajaran yang meliputi Rencana Pelaksanaan Pembelajaran (RPP), Lembar Kerja Siswa (LKS) dan Tes Kreativitas Siswa.

Model yang digunakan untuk pengembangan perangkat pembelajaran adalah model yang dikemukakan Plomp (dalam Rochmad, 2011) dengan kriteria kualitas suatu produk oleh Nieveen (1999).

Tahap-tahap pengembangan perangkat adalah sebagai berikut (Budiarti,2015).

1.Tahap Investigasi Awal

Pada tahap ini aktivitas yang dilakukan meliputi: (1) melakukan kajian teori (2) melakukan kajian tentang pengembangan model pembelajaran, (3) melakukan kajian teori tentang kualitas perangkat yang baik, (4) survei tentang kondisi lapangan yang terkait dengan pembelajaran matematika yaitu materi, siswa dan lingkungan.

2.Tahap Perancangan

Pada tahap ini dirancang perangkat pembelajaran matematika yaitu: Rencana Pelaksanaan Pembelajaran (RPP), Lembar Kerja Siswa (LKS) dan Tes Kreativitas Siswa.

Untuk memperoleh data dirancang instrumen penelitian yang meliputi: lembar validasi, lembar pengamatan pengelolaan pembelajaran dan lembar pengamatan aktivitas siswa 
3. Tahap Realisasi/konstruksi

Tahap realisasi dilakukan untuk menghasilkan perangkat pembelajaran matematika disebut Draf 1.

4. Tahap tes, Evaluasi dan Revisi

Tahap ini mengetahui apakah perangkat memenuhi kriteria perangkat pembelajaran yang baik. Perangkat pembelajaran yang dibuat pada tahap sebelumnya (Draf 1) divalidasi para ahli kemudian di revisi menghasilkan Draf II. Untuk mengetahui kepraktisan dan keefektifan suatu perangkat, Draf II diuji coba terbatas di kelas. Hasil uji coba terbatas di lapangan di analisis untuk menghasilkan Draf Final.

Tabel 1. Waktu Penelitian

\begin{tabular}{|l|l|l|}
\hline Kegiatan & Waktu & Tempat \\
\hline $\begin{array}{c}\text { Perancangan } \\
\text { dan Realisasi } \\
\text { Draf 1 }\end{array}$ & $\begin{array}{l}\text { Mei-Juni } \\
2017\end{array}$ & $\begin{array}{l}\text { STKIP PGRI } \\
\text { Banjarmasin }\end{array}$ \\
\hline Validasi Ahli & Juli 2017 & Banjarmasin \\
\hline $\begin{array}{l}\text { Ujicoba } \\
\text { Terbatas }\end{array}$ & $\begin{array}{l}\text { Agustus } \\
2017\end{array}$ & $\begin{array}{l}\text { SMPN } \\
\text { Banjarmasin }\end{array}$ \\
\hline
\end{tabular}

\section{Teknik Analisis}

Kriteria kualitas perangkat pembelajaran berdasarkan kriteria yang dikemukakan Nieeven, yaitu: valid, praktis dan efektif.

1.Valid, Valid dan layak digunakan (validator) 2.Praktis, praktis jika pengelolaan pembelajaran guru minimal kategori baik.

Tabel 2. Kategori aktivitas siswa dan pengelolaan pembelajarana guru

\begin{tabular}{cl}
\hline Kriteria Standar & Kategori \\
\hline $80 \%<P_{O} \leq 100 \%$ & Sangat baik \\
$60 \%<P_{O} \leq 80 \%$ & Baik \\
$40 \%<P_{O} \leq 60 \%$ & Cukup baik \\
$20 \%<P_{O} \leq 40 \%$ & Kurang baik \\
$0 \%<P_{O} \leq 20 \%$ & Tidak baik \\
\hline
\end{tabular}

(Adaptasi dari Arikunto, 2002)

3.Efektif, efektif jika aktivitas siswa dalam pembelajaran berada pada kategori minimal baik dan $80 \%$ siswa dalam kategori minimal kreatif.

Tabel 3. Kriteria Kreativitas siswa

\begin{tabular}{|c|c|}
\hline $\begin{array}{l}\text { Kriteria } \\
\text { Kreativitas }\end{array}$ & Ciri-ciri \\
\hline $\begin{array}{l}\text { Flue } \\
\text { (kef }\end{array}$ & $\begin{array}{l}\text {-Mencetuskan banyak ide, banyak } \\
\text { jawaban, banyak penyelesaian } \\
\text { masalah, banyak pertanyaan dengan } \\
\text { lancar } \\
\text {-Memberikan banyak cara atau saran } \\
\text { untuk melakukan berbagai hal } \\
\text {-Selalu memikirkan lebih dari satu } \\
\text { jawaban }\end{array}$ \\
\hline & $\begin{array}{l}\text {-Menghasilkan gagasan, jawaban, atau } \\
\text { pertanyaan yang bervariasi, dapat } \\
\text { melihat suatu masalah dari sudut } \\
\text { pandang yang berbeda-beda } \\
\text {-Mampu mengubah cara pendekatan } \\
\text { atau cara pemikiran }\end{array}$ \\
\hline $\begin{array}{l}\text { Originality } \\
\text { (kebaruan) }\end{array}$ & $\begin{array}{l}\text {-Mampu melahirkan ungkapan yang } \\
\text { baru dan unik } \\
\text {-Memikirkan cara yang tidak lazim } \\
\text { untuk mengungkapkan diri } \\
\text {-Mampu membuat kombinasi- } \\
\text { kombinasi yang tidak lazim dari } \\
\text { bagian-bagian atau unsur-unsur }\end{array}$ \\
\hline $\begin{array}{l}\text { Elaboration } \\
\text { (elaborasi) }\end{array}$ & $\begin{array}{l}\text {-Mampu memperkaya dan } \\
\text { mengembangkan suatu gagasan atau } \\
\text { produk } \\
\text {-Menambah atau memerinci detail- } \\
\text { detail dari suatu objek, gagasan, atau } \\
\text { situasi sehingga menjadi lebih } \\
\text { menarik }\end{array}$ \\
\hline
\end{tabular}

Munandar (dalam Hendriana\&Utari, 2014)

Kriteria kreativitas dalam penelitian ini berfokus hanya pada 3 hal yaitu fluency (kefasihan), flexibility (fleksibel), dan originality (kebaruan).

Tabel 4. Kategori kreatifitas siswa

\begin{tabular}{lccc}
\hline \multirow{2}{*}{ Keterangan } & \multicolumn{3}{c}{ Indikator } \\
& Kefasihan & Fleksibel & Kebaruan \\
\hline Sangat & $\sqrt{ }$ & $\sqrt{ }$ & $\sqrt{ }$ \\
Kreatif & - & $\sqrt{ }$ & $\sqrt{ }$ \\
\hline Kreatif & $\sqrt{ }$ & - & $\sqrt{ }$ \\
& $\sqrt{ }$ & $\sqrt{ }$ & - \\
\hline Cukup & - & $\sqrt{ }$ & - \\
Kreatif & - & - & $\sqrt{ }$ \\
\hline Kurang & $\sqrt{ }$ & - & - \\
Kreatif & & & \\
\hline Tidak & - & - & - \\
Kreatif & & & \\
\hline
\end{tabular}

(adaptasi dari Siswono, 2011) 


\section{Hasil Penelitian dan Pembahasan}

\section{Hasil}

Tujuan penelitian ini adalah mendeskripsikan proses pengembangan dan menghasilkan perangkat pembelajaran matematika yang baik mengunnakan model pengembangan Plomp (1997) yang terdiri dari beberapa tahap yaitu (1) Tahap investigasi awal, (2) Tahap perancangan, (3) Tahap realisasi, dan (4) Tahap tes, evaluasi, dan revisi. Kriteria kualitas suatu produk oleh Nieveen (1999) digunakan untuk mendapatkan perangkat pembelajaran baik yaitu (1) valid, (2) praktis, dan (3) efektif.

\section{Tahap investigasi awal}

Pendidikan Matematika Realistik (PMR) merupakan salah satu pendekatan dalam pembelajaran matematika yang dikembangkan oleh Hans Freudenthal. Dia berpendapat bahwa matematika merupakan suatu aktivitas manusia. Realistik yang dimaksudkan tidak sekedar menunjukkan hubungan dengan dunia nyata, tetapi lebih berfokus pada sesuatu yang dapat dibayangkan siswa untuk melakukan matematisasi.

Etnomatematika berasal darikata ethno (budaya yang dibentuk oleh masyarakat), mathema (penjelasan, pemahaman, lingkungan akan budaya), dan tics (mode, gaya, teknik). D'Ambrosio (1977) menjadi "Bapak Intelektual" dari program etnomatematika yang diusulkan sebagai konsep yang lebih luas dari etno atau budaya. Etnomatematika jika diterapkan di kelas akan menjadikan pembelajaran semakinbermakna dan akan lebih baik jika diterapkan di kelas multikultural.

Pengembangan kreativitas dalam pembelajaran masih belum banyak orang yang melakukannya (Mahmudi, 2008). Baron mengartikan kreativitas sebagai kemampuan untuk menghasilkan atau menciptakan sesuatu yang baru. Senada dengannya, Haefele menyatakan kreativitas adalah kemampuan seseorang untuk membuat kombinasikombinasi baru. Selanjutnya, Simpsons menyatakan kemampuan kreatif sebagai inisiatif yang dihasilkan individu dengan kemampuannya untuk mendobrak pemikiran yang biasa (dalam Munandar, 2009).

Model pengembangan yang digunakan adalah model Plomp (dalam Rochmad, 2011). Model Pengembangan Plomp dipilih karena langkah-langkah pengembangan berkaitan dengan pendidikan, tahapan-tahapannya sederhana dan sistematis serta mudah dipahami. Kualitas perangkat pembelajaran yang baik menggunakan tiga kriteria kualitas yang dikemukakan Nieveen (1999) yaitu: valid, praktis dan efektif. Kriteria kualitas Nieveen ini diambil karena berhubungan dengan kualitas produk-produk penelitian pengembangan pembelajaran.

Kajian terhadap materi, siswa dan lingkungan dilakukan peneliti dengan observasi terhadap sekolah dan mengetahui metode pembelajaran yang biasa digunakan oleh guru dalam mengajarkan matematika. SMPN 9 Banjarmasin yang beralamat di Jalan Batu Benawa Raya 25 RT 07 Banjarmasin tengah. Wilayah banjarmasin tengah merupakan wilayah banjarmasin yang memiliki penduduk sebagian besar adalah suku asli banjar. Jika diterapkan ethomathematics, ke khas-an budaya banjar sangat cocok diaplikasikan.

Konsep himpunan adalah dasar bagi konsep matematika yang lain. Materi ini sangat sesuai untuk mengawali pengenalan awal dan pondasi pemahaman konsep yang kokoh untuk siswa. 


\section{Tahap Perancangan}

Sebelum memulai perancangan diperlukan silabus yang dirancang mencakup standar kompetensi, kompetensi dasar, materi pokok/pembelajaran, kegiatan pembelajaran, indikator pencapaian kompetensi untuk penilaian, penilaian, alokasi waktu dan sumber belajar. Dari silabus perangkat pembelajaran dirancang.

a.Rancangan Rencana Pembelajaran

Peremuan dirancang sebnayak 4 kali pertemuan pembelajaran dan 1 kali pertemuan untuk tes akhir. Setiap pertemuan mempunyai alokasi waktu 2x40 menit. Berdasarkan karakteristik PMR yang dikemukakan oleh Hobri (2009), langkah-langkah pembelajaran melalui Pendidikan Matematika Realistik (PMR) berbasis ethnomathematics dirumuskan sebagai berikut.

\section{Penyajian masalah kontekstual}

Guru memberikan soal cerita berupa masalah kontekstual berbasis budaya Banjar yang sesuai dengan tingkat berpikir siswa. Guru meminta siswa untuk memahami masalah yang disajikan. Masalah kontekstual yang diberikan adalah masalah berbasis budaya Banjar yang berkaitan dengan materi aritmatika sosial yang mungkin sudah ada dalam pengalaman siswa sehari-hari. Karakteristik PMR yang ada dalam langkah ini adalah (the use of contex).

\section{Penjelasan masalah kontekstual}

Apabila siswa mengalami kesulitan dalam memahami masalah kontekstual, guru akan mengarahkan siswa pada pemahaman masalah kontekstual tersebut dengan memberikan beberapa pertanyaan. Karakteristik PMR yang ada dalam langkah ini adalah interaksi antar guru dan siswa (interactivity).

3. Penyelesaian masalah kontekstual

Baik secara individu maupun kelompok, siswa menyelesaikan masalah kontekstual dengan berbagai cara. Selanjutnya, masalah kontekstual ditransformasikan dalam bentuk simbol (matematisasi horisontal). Penyelesaian masalah yang muncul mungkin akan berbeda-beda. Karakteristik PMR yang ada dalam langkah ini adalah menggunakan model (use models) dan keterkaitan antar topik dalam matematika (intertwining).

4. Diskusi jawaban masalah kontekstual Guru menyediakan waktu dan kesempatan pada siswa untuk mendiskusikan cara penyelesaian masalah secara berkelompok. Selanjutnya, hasil diskusi kelompok dibawa dalam diskusi kelas. Langkah ini bertujuan untuk melatih siswa mengemukakan ideidenya dan mengajukan pertanyaan agar kreativitas siswa dapat berkembang. Model matematika yang telah diperoleh siswa menjadi landasan untuk membuat kesimpulan konsep matematika yang lebih formal (matematisasi vertikal). Karakteristik PMR yang ada dalam langkah ini adalah kontribusi siswa (student contribution) dan kegiatan interaktif antara siswa dengan siswa yang lainnya (intertwining).

5. Penarikan Kesimpulan

Dari hasil diskusi, guru mengarahkan siswa untuk membuat rangkuman dan kesimpulan tentang cara menyelesaikan masalah kontekstual yang telah dipelajari. Karakteristik PMR yang ada dalam langkah ini adalah interaksi antar guru dan siswa (intertwining).

Pembagian materi dan penggunaan masalah yang berkaitan dengan budaya banjar pada setiap pertemuan adalah sebagai berikut RPP 1, Alokasi waktu : 2 x 40 menit.

Materi : Memahami Konsep himpunan dan diagram Venn;Konsep himpunan, Penyajian himpunan, Konsep himpunan semesta dan diagram venn, Kardinalitas himpunan dan Konsep himpunan kosong. 
Masalah yang disajikan berkaitan dengan kekhas-an budaya banjar khususnya pada ragam makanan, buah dan alat transportasi khas-banjar sebagai objeknya nantinya akan dikelompokkan menjadi sebuah himpunan. RPP 2, Alokasi waktu : 2 x 40 menit.

Materi : Memahami relasi himpunan; Himpunan Bagian dan Himpunan Kuasa.

Masalah yang diberikan berkaitan dengan hewan khas kalimantan selatan yaitu bekantan, macam kesenian daerah kalimantan selatan dan sikap religius orang banjar yaitu kegemaran dalam memeriahkan acara MTQ (Musabaqah Tilawatil Quran).

RPP 3, Alokasi waktu : 2 x 40 menit.

Materi : Memahami operasi himpunan; irisan himpunan dan gabungan himpunan.

Masalah yang disajikan berkaitan dengan

kekhas-an budaya banjar khususnya pada

kerajinan dan tempat pariwisata (pasar

terapung) sebagai objeknya.

RPP 4, Alokasi waktu : 2 x 40 menit.

Materi : Memahami operasi himpunan; operasi komplemen himpunan dan operasi selisih himpunan.

Masalah yang diberikan berkaitan dengan motif-motif batik sasirangan khas kalimantan dan kesenian banjar.

b. Rancangan Lembar Kerja Siswa

LKS dirancang sebagai lembaran tugas atau kegiatan yang dilakukan oleh siswa untuk mengenalkan konsep dan memantapkan materi. Bentuk masalah dalam LKS disajikan berkaitan dengan kekhas-an budaya banjar untuk mendukung pelaksanaan RPP disetiap pertemuan. LKS dirancang dengan memperhatikan tujuan-tujuan yang akan dicapai dalam RPP dan kegiatan yang akan dilakukan dalam pembelajaran PMR berbasis ethnomathematics budaya banjar. c. Rancangan Tes Kreativitas Siswa (TKS)

Tes ini merupakan alat ukur kategori keativitas siswa. TKS berbentuk sebuah soal uraian berupa soal terbuka yang memungkinkan siswa menjawab soal sebanyak-banyaknya. Penyusunan TKS meliputi: kisi-kisi penilaian, kunci jawaban dan pedoman penskoran.

d.Rancangan Lembar Observasi aktivitas siswa dan pengelolaan pembelajaran oleh guru

Lembar observasi dirancang dengan menggunakan lembar observasi aktivitas siswa dan lembar pegamatan pengelolaan pembelajaran pembelajaran matematika.

Hasil tahap ini adalah rancangan perangkat pembelajaran berupa RPP, LKS, TKS, dan instrumen penelitian meliputi: lembar validasi, lembar pengamatan pengelolaan pembelajaran dan lembar observasi aktivitas siswa.

\section{Tahap Realisasi}

Tahap ini adalah lanjutan tahap perancangan dimana telah dihasilkan perangkat pembelajaran dan instrumen penelitian sebagai realisasi perancangan. Hasil-hasil konstruksi ditelaah kembali sehingga dikatakan siap di uji kevalidannya oleh para ahli. Hasil tahap ini disebut sebagai Draf I.

\section{Tahap Tes, Evaluasi dan Revisi}

Draft 1 divalidasi oleh validator kemudian direvisi. Selanjutnya perangkat dikatakan valid dan layak digunakan dalam pembelajaran.

Pada pelaksanaan pembelajaran didapat data Aktivitas Siswa dalam pembelajaran dan pengelolaan pembelajaran oleh guru sebagai berikut. 
Tabel 4. Persentasi aktivitas siswa dan pengelolaan pembelajaran oleh guru

\begin{tabular}{|l|c|c|c|c|l|l|}
\hline \multirow{2}{*}{} & \multicolumn{4}{|c|}{ Pertemuan ke } & \multicolumn{2}{|c|}{ Kesimpulan } \\
\cline { 2 - 7 } & 1 & 2 & 3 & 4 & $\begin{array}{l}\text { Rata- } \\
\text { rata }\end{array}$ & $\begin{array}{l}\text { Kate- } \\
\text { gori }\end{array}$ \\
\hline Siswa & 59,38 & 60,94 & 74,22 & 80,47 & 68,75 & Baik \\
\hline Guru & 60,47 & 76,74 & 83,72 & 88,37 & 77,33 & Baik \\
\hline
\end{tabular}

Dari data di atas persentasi aktivitas pada 4 pertemuan pembelajaran berada pada kategori baik dan presentasi pengelolaan pembelajaran oleh guru pun berada pada kategori baik.

Tes Kreativitas siswa diberikan pada pertemuan akhir. Tes ini untuk mengetahui kategori kreativitas siswa setelah mengikuti pembelajaran.

Tabel 5. Kategori Kreativitas Siswa

\begin{tabular}{|l|c|l|}
\hline Kategori Kreativitas & f & \multicolumn{1}{|c|}{$\%$} \\
\hline Sangat Kreatif & 4 & 12,90 \\
\hline Kreatif & 21 & 67,74 \\
\hline Cukup Kreatif & 1 & 3,23 \\
\hline Kurang Kreatif & 5 & 16,13 \\
\hline Tidak Kreatif & 0 & 0,00 \\
\hline
\end{tabular}

Dari data di atas total persentasi siswa dengan kategori minimal kreatif sebanyak $80,64 \%$ dimana persentasi siswa berkategori kreatif $67,74 \%$ dan siswa berkategori sangat kreatif sebanyak $12,90 \%$.

\section{Pembahasan}

Pengembangan

perangkat pembelajaran ini menghasilkan perangkat pembelajaran yang baik yaitu yang memenuhi kriteria valid, praktis dan efektif.

\section{Kevalidan}

Perangkat pembelajaran yang dikembangkan divalidasi terlebih dahulu oleh pakar atau ahli. Berdasarkan saran dari validator maka RPP diperbaiki sebelum digunakan. Hasil validasi menunjukan bahwa penilaian validator terhadap RPP, LKS dan TKS memenuhi kriteria valid dan layak digunakan dengan sedikit revisi.

\section{Kepraktisan}

Kepraktisan perangkat pembelajaran diperoleh berdasarkan lembar observasi pengelolaan pada setiap pertemuan. Berdasarkan lembar observasi pengelolaaan pembelajaran diketahui bahwa seluruh pembelajaran matematika terlaksana dengan baik. Dengan demikian dapat disimpulkan bahwa perangkat pembelajaran pendidikan Matematika Realistik (PMR) berbasis Ethnomathematics sebagai upaya mengembangkan kreativitas siswa dinyatakan praktis.

\section{Keefektifan}

Keefektifan perangkat pembelajaran dilihat dari aktivitas siswa dan kategori kreativitas siswa. Rata-rata aktivitas siswa disetiap pertemuan berada pada kategori baik dan $80,64 \%$ siswa berada pada kategori minimal kreatif. Dengan demikian, jika ditinjau dari aspek aktivitas siswa dan kategori kreativitas maka perangkat pembelajaran memenuhi kriteria efektif.

\section{Simpulan dan Saran}

\section{Simpulan}

\section{Pengembangan}

perangkat pembelajaran pembelajaran pendidikan matematika realistik (PMR) berbasis ethnomathematics sebagai upaya mengembangkan kreativitas siswa yang memenuhi kriteria perangkat pembelajaran yang baik yaitu valid, praktis, dan efektif. Perangkat pembelajaran ini berupa Rencana Pelaksanaan Pembelajaran (RPP), Lembar Kerja Siswa (LKS) dan Tes Kreativitas Siswa (TKS) . 


\section{Saran}

a. Guru

Setelah dilakukan penelitian ini, diharapkan guru dapatmengaplikasikan pembelajaran matematika melalui Pendidikan Matematika Realistik (PMR) berbasis ethnomathematics pada materi matematika yang lain untuk mengembangkan kreativitas siswa.

b. Siswa

Siswa lebih berperan aktif dalam pembelajaran matematika melalui Pendidikan Matematika Realistik (PMR) berbasis ethnomathematics sehingga dapat mengembangkan kreativitasnya dan menjadi dasar yang kuat untuk mempelajari materi pada tingkat selanjutnya.

c.SMPN 9 Banjarmasin

Sekolah sebaiknya mengembangkan pembelajaran melalui Pendidikan Matematika Realistik (PMR) berbasis ethnomathematics dengan memanfaatkan keragaman budaya setempat.

d. Peneliti

Peneliti yang akan melakukan penelitian serupa diharapkan mengembangkan perangkat pembelajaran dengan materi matematika yang lain.

\section{Daftar Pustaka}

Arikunto, S. 2002. Prosedur Penelitian Suatu Pendekatan Praktek. Jakarta: Rineka Cipta.
Budiarti, Indah. 2015. Pengembangan Perangkat Pembelajaran Matematika Metode Montessori Untuk Materi Pokok Trapesium Dan LayangLayang Di Kelas V Sekolah Dasar. Banjarmasin: Jurnal Lentera Vol 10 No 2.

D'Ambrosio U. 1997. Ethnomathematics and its Place in the History and Pedagogy of Mathematics. In A. Powell \& M. Frankenstein(eds.), Ethnomathematics, Challenging Eurocentrismin Mathematics Education. Albany: State University of New York Press.

Gravemeijer, K., Doorman, M. 1999. Context Problem in Realistic Mathematics Education: A Calculus Course as An Example. Netherlands: Kluwer Academic Publishers.

Hendriana, H., \& Utari Soemarmo. 2014. Penilaian Pembelajaran Matematika. Bandung: Refika Aditama.

Hobri. 2009. Model-model Pembelajaran Inovatif. Jember: Center of Society Studies.

Kemdikbud. 2013. Peraturan Menteri Pendidikan dan Kebudayaan Republik Indonesia Nomor 65 Tahun 2013 TentangStandar Proses Pendidikan Dasar dan Menengah. Jakarta: Kementrian Pendidikan dan Kebudayaan.

Kemdikbud. 2013. Peraturan Menteri Pendidikan dan Kebudayaan Republik Indonesia Nomor 103 Tahun 2014 TentangPembelajaran Pada Pendidikan Dasar dan Menengah. Jakarta: Kementrian Pendidikan dan Kebudayaan. 
Mahmudi, A. 2008. Tinjauan Kreativitas dalam Pembelajaran Matematika. Jurnal Pythagoras Jurusan Pendidikan Matematika FMIPA UNY, Vol.4, Nomor 2, Desember 2008, ISSN 1978-4538.

Munandar, S.C.U. 2009. Mengembangkan Bakat dan Kreativitas Anak Sekolah. Jakarta: Gramedia.

Ngalimun, dkk. 2013. Perkembangan dan Pengembangan Kreativitas. Yogyakarta: Aswaja Pressindo.

Ningsih, Seri. 2014. Realistic Mathematics Education: Model Alternatif Pembelajaran Matematika Sekolah. Jurnal Pendidikan Matematika, Vol.01, Nomor 22, Juni 2014, ISSN 2354-9645.

Rochmad, 2011. Model Pengembangan Perangkat Pembelajaran Matematika. Unnes : Jurusan Matematika FMIPA

Nieveen. 1999. Prototyping to Reach Product Quality. University of Twenty, The Nederlands

Royani, Muhammad, Winda Agustina. 2017. Bentuk-bentuk Geometris pada Pola Kerajinan Anyaman sebagai Kearifan Lokal di Kabupaten Barito Kuala. Jurnal Pendidikan Matematika, Vol.3, Nomor 2, eISSN 2579-3977.

Wijaya, A. 2012. Pendidikan Matematika Realistik; Suatu Alternatif Pendekatan Pembelajaran Matematika. Yogyakarta: Graha Ilmu. 